\title{
Pengujian Aplikasi Peminjaman Kendaraan Operasional Kantor Menggunakan BlackBox Testing
}

\author{
Jafar Shadiq ${ }^{1,}$, Ahmad Safei ${ }^{1}$, Rayhan Wahyudin Ratu Loly ${ }^{1}$ \\ ${ }^{1}$ Rekayasa Perangkat Lunak; Universitas Bina Insani; JI.Siliwangi No.6 Rawa Panjang Rawa \\ Lumbu Bekasi, (021) 82400924; e-mail: jafarshadiq@binainsani.ac.id, syafei456@gmail.com \\ rayhan.wahyudin21@gmail.com \\ * Korespondensi: e-mail: jafarshadiq@binainsani.ac.id
}

Diterima: 29 Juni 2021 ; Review: 30 Juni 2021; Disetujui: 27 Juli 2021

Cara sitasi: Shadiq J, Safei A, Loly RWR. 2021. Pengujian Aplikasi Peminjaman Kendaraan Operasional Kantor Menggunakan BlackBox Testing. Information Management for Educators and Professionals. Vol 5 (2): 97-110

\begin{abstract}
Abstrak: Pengujian black-box begitu penting karena teknik tersebut mampu mengidentifikasi kesalahan dalam fungsi, antar muka, model data, dan akses kesumber data eksternal. Dalam pelaksanaan sering timbul masalah penguji tidak pernah yakin apakah perangkat lunak yang diuji telah benar-benar lolos dalam pengujian. Hal ini terjadi karena kemungkinan masih ada beberapa jalur eksekusi yang belum pernah teruji. Penguji seharusnya membuat setiap kemungkinan kombinasi data masukan untuk pengujian. Pemilihan data masukan untuk menemukan kesalahan menjadi masalah bagi penguji karena memiliki probabilitas yang tinggi, sehingga desain test case secara otomatis dapat menjadi solusi. Pada implementasi ini aplikasi yang akan di uji menggunakan black-box testing adalah sebuah Sistem Informasi peminjaman kedaraan operasional. Aplikasi peminjaman kendaran operasional tersebut akan diuji menggunakan black-box testing di mana pengujian ini hanya bertujuan untuk melihat program tersebut apakah sesuai dengan fungsi yang diinginkan program tersebut tanpa mengetahui kode program yang dipakai. Untuk menghasilkan desain test case secara otomatis dalam pengujian perangkat lunak metode black-box dengan teknik equivalence partitioning. Teknik Equivalence Partitions adalah pengujian didasarkan masukkan data pada setiap form yang ada pada aplikasi di setiap menu akan dilakukan pengujian dan dikelompokkan berdasarkan fungsinya baik itu bernilai valid ataupun tidak valid.
\end{abstract}

Kata kunci: Equivalence Partitions, black-box, Aplikasi, Peminjaman Kendaraan Operasional, test case

Abstract: Black-box testing is very important because the technique is able to identify errors in functions, interfaces, data models, and access to external data sources. In implementation, the problem often arises that the tester is never sure whether the software being tested has actually passed the test. This happens because there may still be some untested execution paths. The tester must make every possible combination of input data for testing. The selection of input data to find errors is a problem for the examiner because it has a high probability, so that the test case design can automatically be a solution. In this implementation, the application that will be tested using black-box testing is an operational vehicle loan information system. The operational vehicle loan application will be tested using black-box testing where this test only aims to see whether the program is in accordance with the desired function of the program without knowing the program code used. To generate test case designs automatically in software testing the black-box method with equivalence partitioning techniques. The Equivalence Partitions technique is a test based on data on every form in the management information system, each menu will be tested and assessed for application on usefulness, whether it is feasible or not valid.

Keywords: Equivalence Partitions, black-box, Aplplication, Operational Vehicle Loan, test case 


\section{Pendahuluan}

Perkembangan pada bidang teknologi menjadi dasar utama perusahaan untuk berlombalomba dalam mempertahankan sektor bisnis sehingga perusahaan mampu bersaing dengan perusahaan-perusahaan lain terutama pada bidang bisnis yang sama. Perusahaan saling bertukar informasi dan saling unjuk gigi di berbagai media supaya perusahaan tersebut tetap berdiri. Persaingan perusahaan yang semakin cepat dengan teknologi yang telah diterapkan guna membangun seluruh kegiatan bisnis menjadi lancar.

Kegiatan-kegiatan perusahaan untuk meningkatkan daya bisnis dan daya saing berbagai cara untuk mendapatkan patner di luar perusahaan sehingga perusahaan melakukan kegiatan usahanya di luar. Bentuk kegiatan diluar perusahaan seperti bertemu dengan rekan bisnis, rapat khusus dan kegiatan lainnya di luar perusahaan. Demi menunjang kegiatan diluar perusahaan tentu mendorong perusahaan untuk memiliki alat transportasi.

Transportasi merupakan alat angkut yang sangat diperlukan dikalangan para pengembang ekonomi yaitu perusahaan untuk mendorong lajunya pertumbuhan ekonomi sehingga tujuan dari pengembang ekonomi dapat tercapainya dan sesuai dengan yang diharapkan [1]. Transportasi dapat dibilang kendaraan operasional kantor. Salah satu asset pada perusahaan dan dapat menunjang seluruh kegiatan diluar perusahaan yaitu kendaraan operasional.

Moda transportasi merupakan sarana yang dimiliki oleh seseorang atau sekelompok orang (organisasi) untuk melakukan transfer baik manusia atau barang dari satu tempat ke tempat lainnya dengan melalui berbagai jalur transfer seperti darat, laut, dan udara bergantung kepada karakteristik dari sarana tersebut. Moda transportasi kepemilkan Bersama atau perusahaan dapat disebut dengan kendaraan operasional [2].

Berdasarkan dari pengertian tersebut bahwa kendaraan operasional yang dimiliki oleh perusahaan guna memenuhi kebutuhan para karyawan dalam menjalankan tugas di luar perusahaan tempat bekerja. Kendaraan operasional memiliki karakteristik tersendiri yang akan dipilih oleh karyawan menuju ke suatu tempat sesuai lokasi atau tempat tujuannya serta penggunaan wewenang yang sudah ditetapkan oleh perusahaan tentang standar penggunaan kendaraan operasional harus di jaga sebaik mungkin.

Kendaraan operasional yang dimiliki perusahaan tergantung seberapa besar kegiatan ekternal yang dilakukan opeh perusahaan. Perusahaan yang besar akan memilki kendaraan operasional dengan jumlah yang banyak pula karena perusahaan besar tentu akan mengalami kepadatan kegiatan di luar perusahaan.

Kepadatan penggunaan kendaraan operasional oleh perusahaan diharapkan adanya pengelolaan yang efektif dan efisien sehingga perusahaan mampu menjalankan bisnis dengan lancar. Pengelolaan kendaraan operasional dapat dibuat dengan teknologi sistem informasi berdasarkan perkembangan teknologi dan dunia saing.

Permasalahan yang terjadi di perusahaan terutama terkait pengelolaan kendaraan operasional adalah sulitnya mengajukan pemakaian kendaraan operasional dikarenakan kepengurusan tersebut diberikan wewenang kepada manajer perusahaan dengan pekerjaan yang sangat padat dan sangat sulit ditemui oleh karyawan atau unit lain yang ingin mengajukannya.

Selain itu melakukan pengajuan pemakaian kendaraan operasional dengan membutuhkan waktu yang cukup lama dan Panjang, tidak sedikit surat yang harus di isi dan di verifikasi oleh atasan pengaju dan manager sehingga pengajuan pemakaian menjadi sulit dan karyawan dari berbagai divisi tidak sedikit menggunakan kendaraan pribadinya masing-masing untuk memenuhi tugasnya di luar perusahaan. 
Salah satu contoh masalah yang sering ditemui pada divisi marketing. Divisi marketing ini yang profesionalitasnya banyak menghabiskan waktu di luar perusahaan untuk mempromosikan produk perusahaan baik jasa dan barang dan setiap dari bagian divisi marketing harus melakukan pengajuan peminjaman kendaraan operasional jauh sebelum kegiatan dilaksanakan dan tidak semua pengajuan di terima dan diverifikasi atas hal prioritas lain yang harus diutamakan.

Permasalahan lain timbul setelah pengajuan kendaraan operasional dan beberapa form yang harus di isi dan diserahkan kepada manajer tertumpuk di meja dan tertutup oleh dokumendokumen lain sehingga surat pengajuan yang tertutup oleh dokumen lain tersebut tidak atau telat untuk diverifikasi oleh manajer. Akibatnya karyawan yang mengajukan tersebut menggunakan kendaraan pribadinya.

Permasalahan yang sudah dipaparkan sebelumnya bahwa sangat penting perusahaan dapat memutuskan untuk mengembangkan sistem informasi aplikasi dalam mengelola kendaraan operasional. Aplikasi yang akan di implementasikan dapat dijadikan sebuah terobosan baik untuk perusahaan dalam menjalankan bisnisnya dan tentunya pengelolaan kendaraan melalui aplikas akan lebih efisien dan efektif selain itu perusahaan dapat mewujudkan sistem paperless.

Sistem informasi pengelolaan kendaraan operasional berbasis website ini dikembangkan sendiri oleh perusahaan dengan fungsi khusus untuk mengelola penggunaaan kendaraan operasional serta aplikasi dapat di akses dimanapun dan kapan pun tanpa harus menggunakan secarik kertas dan hanya menggunakan perangkat seperti komputer, laptop atau smartphone sehinga memudahkan untuk semua devisi akan mengajukan penggunaan kendaraan operasional tersebut.

Aplikasi pengelolaan kendaraan operasional ini memiliki beberapa modul yang telah disesuaikan sesuai dengan kebutuhan perusahaan diantaranya terdapat modul pengelolaan user, modul pengelolaan departemen, modul pengelolaan perusahaan cabang, modul pengelolaan kendaraan, modul pengelolaan supir, modul pengelolaan karyawan, modul pengelolaan hak akses, modul pengelolaan session login, modul pengelolaan riwayat login, modul pengelolaan data pengajuan peminjaman baru, modul pengelolaan verified pengajuan, modul pengelolaan laporan, modul pengelolaan transaksi, modul pengelolaan pengembalian kendaraan dan modul laporan. Semua tersirat dalam satu aplikasi yang saling terintegrasi dengan lainnya.

Aplikasi pengelolaan kendaraan operasional yang telah di implementasi ini menggunakan metode pengembangan yaitu metode pengembangan extreme programming. Metode pengembangan ini saat ini sangat sering oleh para penganalisa sistem informasi pada umumnya karena metode pengembangan ini lebih efisien, cepat, fleksibel, beresiko rendah, scientific dan banyak digemari [3]. Metode memilki nilai yaitu Nilai tersebut adalah communication, simplicity, feedback, dan courage [4].

Pengujian aplikasi merupakan proses yang dilakukan kepada sebuah program bermaksud untuk menemukan kesalahan-kesalahan yang kemungkinan tidak dapat terlacak atau ditemukan dalam pembuatan atau melewatkan sebuah flow yang sudah ditetapkan sebelumnya dengan cara test yang sistematik disemua fungsi program sejalan dengan flow working pada program tersebut sehingga program dapat di katakana layak untuk digunakan secara berkala [5].

Pengujian aplikasi pengelolaan kendaraan operasional dapat di test setelah melalui fase penggunaan aplikasi tersebut dalam kurun waktu lama dan hasil dari pengujian dapat di jadikan sebuah re-circle serta perbaikan untuk menuju aplikasi fungsional.

Program yang akan dibuat pada pengkajian ini adalah program sistem seleksi sales terbaik adalah Blackbox Testing, di mana pengujian bertujuan melihat program tersebut sama dengan tugas program tersebut tanpa mengetahui kode program yang dipakai. 
Tahapan pertama padapengujian dengan menggunakan Blackbox Testingadalah mengidentifikasi masukan lalu diuji agarkita mengetahui letak kesalahannya.

Ada beberapa cara dalam menguji Black Box Testing salah satunya adalah mengunakan teknik Equivalence Partitions. Equivalence Partitions merupakan sebuah pengujian berdasarkanmasukkan data pada setiap form yang ada padasistem seleksi sales terbaik, setiap menu masukanakan dilakukan pengujian dan dikelompokkan berdasarkan fungsinya baik itu bernilai validataupun tidak valid [6].

\section{Metode Penelitian}

Pengujian aplikasi pengelolaan kendaraan operasional merupakan suatu kegiatan yang sangat dibutuhkan oleh programmer atau pengembangan sistem saat penemuan error yang terjadi pada aplikasi tersebut sehingga pengembang sistem dapat mengetahui langkah kedepan yang harus dikerjakan dengan panduan dokumen-dokumen analisis dan design program pengelolaan kendaraan operasional tersebut [7]. Maka itu pengujian pada aplikasi pengelolaan kendaraan operasional sangat diperlukan, mengingat dari penjelasan sebelumnya bahwa terjadinya error akan memperhambat lajunya sistem. Pengujian dilakukan secara verifikasi dan validasi dengan landasan hasil analisis kebutuhan perusahaan yang sudah dilakukan dan melakukan beberapa evaluasi apabila terjadi ketidaksamaan pada pengembangan aplikasi pengelolaan kendaraan operasional yang segera dilakukan perbaikan guna menyesuaikan kebutuhan perusahaan [8]. Pengujian sistem informasi pengelolaan kendaraan operasional yang diimplementasikan adalah pengujian Blackbox Testing.

Metode Blackbox Testing adalah metode merupakan pengujian yang berfokus pada spesifikasi fungsional dari perangkat lunak, tester dapat mendefinisikan kumpulan kondisi input dan melakukan pengetesan pada spesifikasi fungsional program [9]. Proses Black Box Testing dengan cara mencoba program yang telah dibuat dengan mencoba memasukkan data pada setiap formnya. Pengujian ini diperlukan untuk mengetahui program tersebut berjalan sesuai dengan yang dibutuhkan oleh perusahaan [10]. Pengujian dengan metode Blackbox Testing memiliki dua teknik yaitu Equivalence Partitioning dan Boundary Value Analysis [11]. Pada penelitian ini menggunakan teknik Equivalence Partitioning. Pengujian Black box memakai metode Equivalence Partitioning. Yaitu meliputi penentuan test case, penentuan kriteria, pendefinisian partisi, pembuatan data uji, pembuatan kasus uji, serta terakhir pengujian dan evaluasi [12].

Pengujian Black Box Equivalence Partitioning yang akan di implementasikan pada aplikasi peminjaman kendaraan operasional ini diantaranya: 1). Pengujian fungsionalitas pada halaman login, 2). Pengujian fungsionalitas pada halaman transaksi pengajuan peminjaman kendaraan operasional kantor 3). Pengujian fungsionalitas halaman transaksi konfirmasi peminjaman, 4). Pengujian fungsionalitas pada halaman transaksi pengembalian dan 5). Pengujian fungsionalitas halaman laporan.

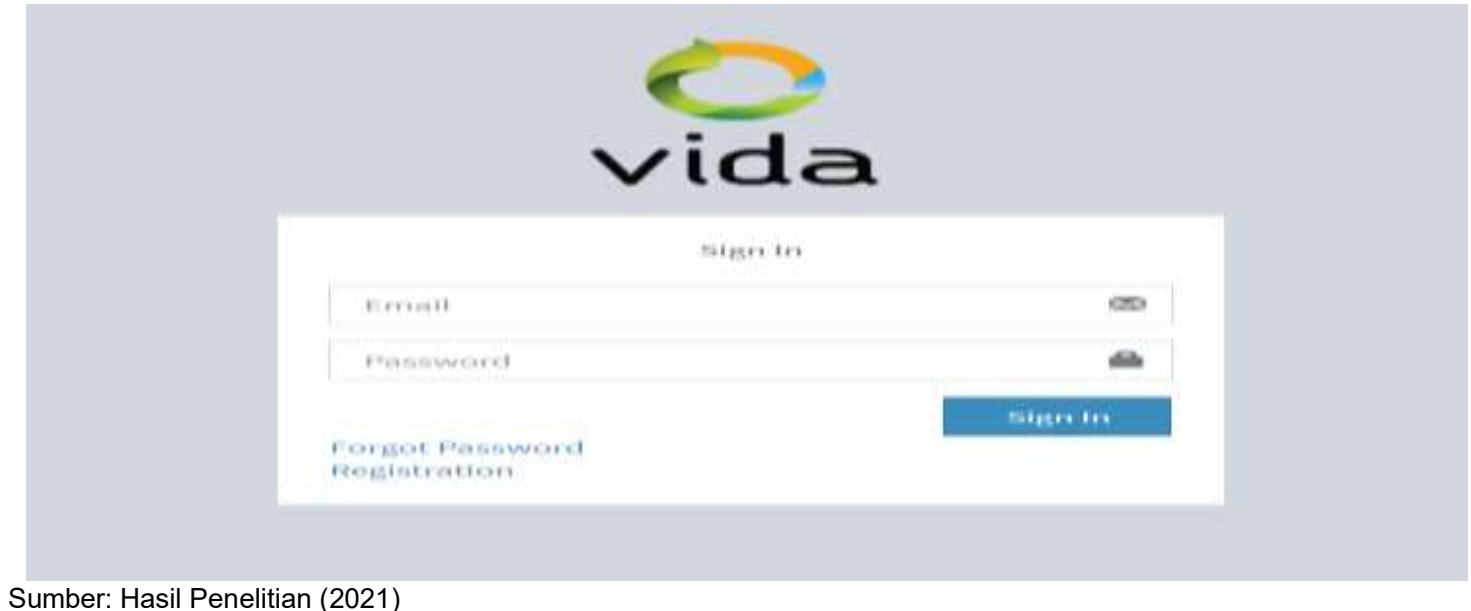

Sumber: Hasil Penelitian (2021)

Gambar 1. Gambar Halaman Login 
Perhatikan gambar 1 diatas. Halaman login yang digunakan untuk akses masuk oleh para pengguna dengan berbagai session access level baik dari level admin, manager dan karyawan. Akses login diawali dengan akses login sebagai admin akan valid apabila email diisi dengan "admin@example.com" dan password diisi dengan "Admin123!!".

Kemudian login disisi manajer akan valid apabila email diisi dengan "manager@gmail.com" dan password diisi dengan "Manager_321" dan login akan valid disisi karyawan jika dengan isi email "jumari@gmail.com" dan password dengan "jumari".

Setelah email dan password telah diisi dari berbagai level, selanjutnya klik button "Sign In" maka secara sistem akan menuju ke halaman dashboard. Lantas apabila pengisian email dan password salah, baik dari pengisian email dan atau password, sebagai satu contoh login disisi karyawan denga isi email "jumarri@gmail.com" dan isi password "jumai" maka akan muncul sebuah pop up message dengan tulisan "Mohon maaf email dan password salah, silahkan anda periksa kembali" dan apabila tidak diisi baik dari email dan atau password maka akan muncul pop up message dengan tulisan "Email dan Password tidak boleh kosong.

Harap diperiksa terlebih dahulu". Apabila terjadi kesalahan dalam melakukan akses login, selain memunculkan pesan juga isi password akan tereset atau kembali kosong dan diisi ulang oleh pengguna. Berikut dibawah ini merupakan tabel skenario test case yang akan di uji pada fungsionalitas serta validitas dari halaman login.

Tabel 1. Skenario test case halaman login

\begin{tabular}{|c|c|c|}
\hline Kode & Skenario Test & Hasil yang diharapkan \\
\hline A01 & $\begin{array}{l}\text { Email = admin@example.com dan password = } \\
\text { Admin123!! (untuk level admin), Email = } \\
\text { manager@gmail.com dan password = } \\
\text { Manager_321 (untuk level manajer) dan Email = } \\
\text { jumari@gmail.com dan password = jumari } \\
\text { (untuk level karyawan). Setelah itu klik button } \\
\text { "Sign In". }\end{array}$ & $\begin{array}{l}\text { Sistem akan membaca dan memproses kemudian } \\
\text { sistem mengarahkan kepada halaman dashboard. }\end{array}$ \\
\hline A02 & $\begin{array}{l}\text { Pengisian dengan level admin sebagai satu } \\
\text { contoh yaitu Email = admin@example.com dan } \\
\text { password = Admin123! }\end{array}$ & $\begin{array}{l}\text { Sistem akan membaca dan memproses kemudian } \\
\text { sistem menampilkan pop up message dengan tulisan } \\
\text { "Mohon maaf email dan password salah, silahkan anda } \\
\text { periksa kembali" dengan dua button yaitu button "Yes" } \\
\text { untuk mengulang dan button "No" untuk stop akses. }\end{array}$ \\
\hline A03 & Email dan atau password kosong & $\begin{array}{l}\text { muncul pop up message dengan tulisan "Email dan } \\
\text { Password tidak boleh kosong. Harap diperiksa terlebih } \\
\text { dahulu". }\end{array}$ \\
\hline
\end{tabular}

Sumber: Hasil Penelitian (2021)

Perhatikan pada Tabel 1. Skenario test case halaman login diatas. Terdapat tiga kolom yaitu kolom kode, scenario dan hasil yang diharapakan. Kode ditulis dengan "A01" artinya skenario pada tahap pengujian pertama, mengambil huruf alfabet pertama sebagai identitas dari sebuah tahap pertama dan angka "01" sebagai identitas urut test case. Skenario test berisikan beberapa cara pengujian pada halaman login yang terdapat tiga cara pengujiannya diantaranya data yang diisi sesuai dan data yang diisi tidak sesuai dan pada kolom hasil yang diharapkan yaitu setelah seknario di ujikan maka ada timbal balik dari proses login aplikasi dari sisi admin, manager dan karyawan.

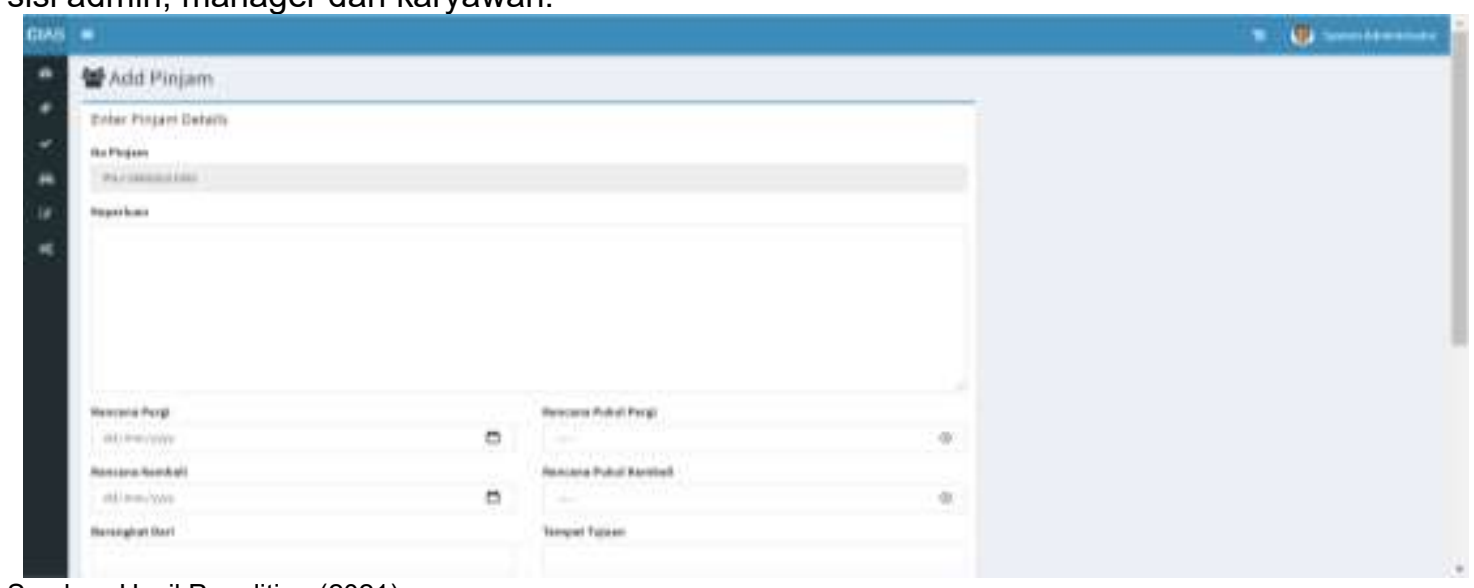

Sumber: Hasil Penelitian (2021)

Gambar 2. Gambar Halaman Pengajuan Peminjaman Kendaraan Operasional. 
Selanjutnya adalah rencana pengujian pada fungsional pengajuan peminjaman kendaraan operasional. Form pada halaman ini harus di isi mulai dari keperluan hingga catatan. Kode di buat secara otomatis. Semua data harus isi karena data-data tersebut penting untuk laporan pengajuan peminjaman yang nantinya akan di konfirmasi di fitur konfirmasi kendaraan. Setelah semua form telah terisi, selanjutnya dapat klik button "Simpan" untuk menyimpan datadata dari halaman ini dan muncul pop up message dengan tulisan "Data berhasil disimpan".

Jika salah satu form tidak terisi atau kosong dan klik button "Simpan" maka akan muncul pop up message dengan tulisan "Data tidak boleh kosong, silahkan cek kembali".

Berikut tabel skenario test case fungsional pada halaman pengajuan peminjaman kendaraan operasional dibawah ini.

Tabel 2. Skenario test case halaman Pengajuan peminjaman Kendaraan Operasional

\begin{tabular}{cll}
\hline Kode & \multicolumn{1}{c}{ Skenario Test } & \multicolumn{1}{c}{ Hasil yang diharapkan } \\
\hline B01 & Form terisi semua & $\begin{array}{l}\text { Muncul pop up mesaage dengan tulisan "Data berhasil } \\
\text { disimpan" dan direct ke halaman list pengajuan } \\
\text { peminjaman kendaraan operasional. }\end{array}$ \\
\hline B02 & Salah satu form tidak terisi & $\begin{array}{l}\text { Muncul pop up mesaage dengan tulisan "Data tidak } \\
\text { boleh kosong, silahkan cek kembali" selanjutnya untuk } \\
\text { melanjutkan pengisian dapat klik "Ok" dan apabila tidak } \\
\end{array}$ \\
& $\begin{array}{l}\text { lanjut pengisian dapat klik "No" dan langsung mengarah } \\
\text { kepada halaman list pengajuan peminjaman kendaraan } \\
\text { operasional. }\end{array}$ \\
\hline
\end{tabular}

Sumber: Hasil Penelitian (2021)

Tabel 2 diatas menyatakan pada skenario test jika form yang telah terisi semuanya maka data-data yang ada pada form tersebut diharapkan tersimpan dalam database dan menampilkan pesan jika data berhasil disimpan kemudian secara otomatis akan mengarah kepada halaman list pengajuan peminjaman. Sebaliknya jika salah satu form kosong atau lupa terisi maka akan hasil yang diharapkan akan tampil pesan bahwa data pada form harus terisi semua dan tidak diperkanankan kosong, kemudian pada pesan tersebut terdapat dua pilihan yaitu "Yes" dan "No". Apabila klik "Yes" maka pengguna atau sipangaju dapat mengulang dan mengecek pengisian sebelumya dan jika pilih "No" maka langsung mengarah list pengajuan peminjaman.

List pengajuan peminjaman kendaraan operasional hanya dapat tampil milik pengguna sendiri sesuai dengan session login sehingga data akan menjadi lebih rapih dan memudahkan dalam mencari informasi.

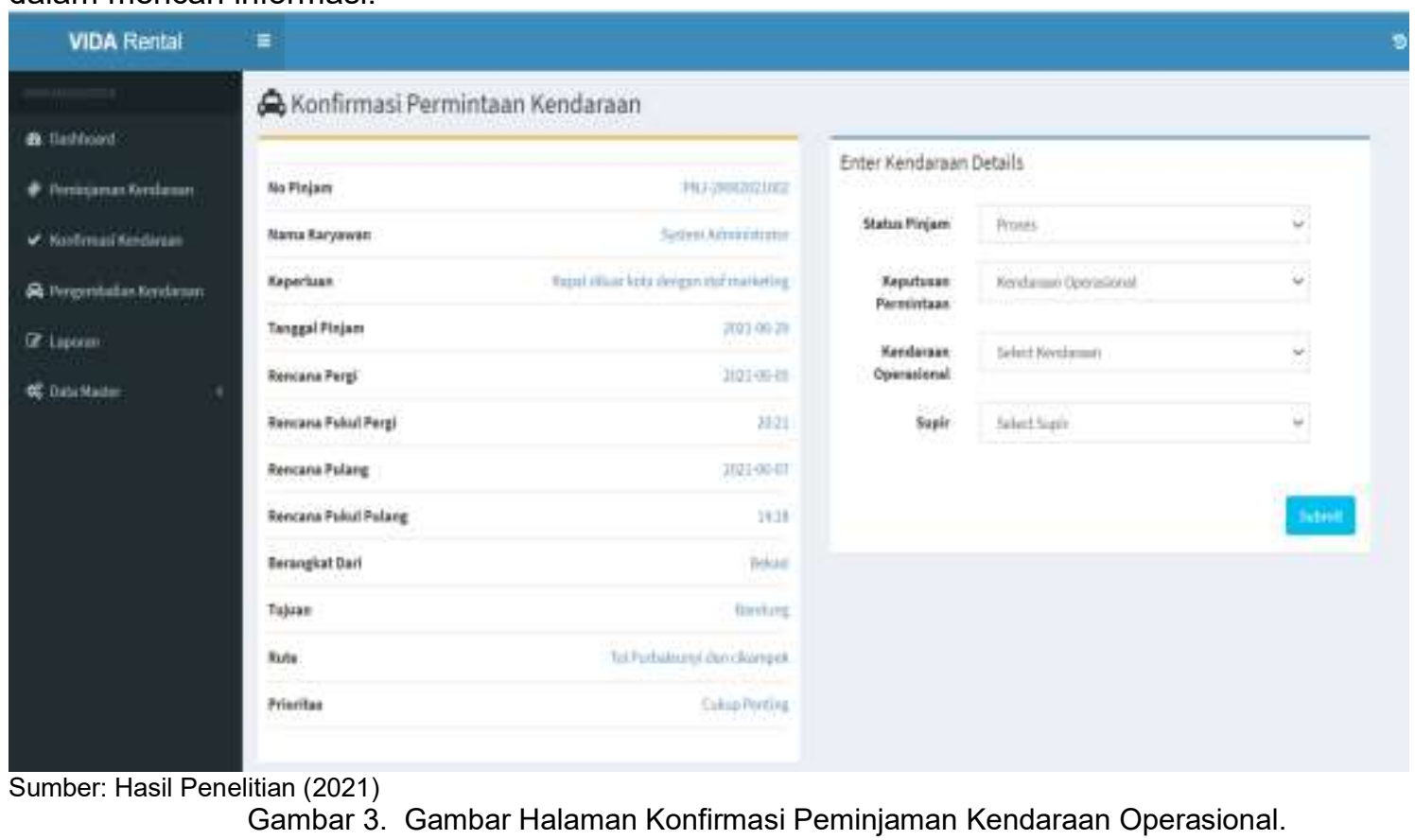


Gambar 3 yaitu halaman konfirmasi peminjaman kendaraan opersional yang hanya dapat diopersikan oleh pengguna pada level Admin dan Manager. Pada halaman ini terdapat form yang harus dilengkapi dari data pengajuan yang telah dibuat. Terdapat form status pinjam dengan isi "Proses" secara default karena pada proses ini masuk dalam tahap pengajuan akan diproses, selanjutnya terdapat form keputusan peminjaman dengan tool menggunakan combobox untuk memberikan pernyataan bahwa pengaju telah mengajukan peminjaman kendaraan. Selanjutnya dengan form kendaraan opersional dan supir menggunakan tool yaitu combobox untuk memilih kendaraan dan supir yang masih tersedia.

Apabila tidak tersedia baik dari kendaraan atau supir maka pemilik akses tidak dapat melanjutkan proses konfrimasi peminjaman untuk yang mengajukan. Proses pengisian berawal dari pemilihan keputusan peminjaman dengan isi "Kendaraan Operasional" selanjutnya di pilih kendaraan dengan isi "B $3022 \mathrm{KL}$ " kemudian pilih supir dengan isi "Budi", setelah itu klik button "submit" maka muncul sebuah pesan yang menyatakan bahwa pengajuan telah diproses dengan menampilkan pop up message. Kemudian halaman akan mengarahkan kepada list konfirmasi pengajuan peminjaman kendaraan operasional.

Sebaliknya, apabila pilihan kendaraan tidak tersedia dan supir juga tidak tersedia dan atau salah salah satunya tidak terpilih (dalam tulisan "Select kendaraan" atau "Select supir" maka data tidak dapat diproses sehingga akan tampil pesan yang menyatakan bahwa konfirmasi tidak dapat diproses karena kendaraan dan supir tidak tersedia dengan pop up mesaage.

Data yang tampil pada pilihan form kendaraan dan supir merupakan hasil tarik data langsung dari database dengan syarat bahwa kendaraan dalam keadaan layak jalan dan mangkir, kemudian syarat supir adalah status supir yaitu aktif dan tidak sedang bertugas. Pernyataan tersebut dapat di breakdown dalam bentuk tabel skenario test case pada dibawah ini.

Tabel 3. Skenario test case Halaman Konfirmasi Peminjaman Kendaraan Operasional

\begin{tabular}{|c|c|c|}
\hline Kode & Skenario Test & Hasil yang diharapkan \\
\hline C01 & $\begin{array}{l}\text { Status }=\text { Proses, Keputusan peminjaman = } \\
\text { Kendaraan Operasional, Kendaraan = B } 3022 \\
\mathrm{KL} \text {, Supir = Budi }\end{array}$ & $\begin{array}{l}\text { Muncul pop up mesaage dengan tulisan "Data berhasil } \\
\text { diproses" dan mengarah ke halaman list konfirmasi } \\
\text { pengajuan peminjaman kendaraan operasional. }\end{array}$ \\
\hline $\mathrm{CO2}$ & $\begin{array}{l}\text { Status = Proses, Keputusan peminjaman = } \\
\text { Kendaraan Operasional, Kendaraan = Select } \\
\text { Kendaraan, Supir = Budi }\end{array}$ & $\begin{array}{l}\text { Muncul pop up mesaage dengan tulisan "Data tidak } \\
\text { dapat diproses, status kendaraan sedang sibuk" } \\
\text { selanjutnya dapat klik "No" dan langsung mengarah } \\
\text { kepada list konfirmasi pengajuan peminjaman } \\
\text { kendaraan operasional. }\end{array}$ \\
\hline C03 & $\begin{array}{l}\text { Status = Proses, Keputusan peminjaman = } \\
\text { Kendaraan Operasional, Kendaraan = B } 3022 \\
\text { KL, Supir = Select Kendaraan }\end{array}$ & $\begin{array}{l}\text { Muncul pop up mesaage dengan tulisan "Data tidak } \\
\text { dapat diproses, status supir sedang sibuk" selanjutnya } \\
\text { dapat klik "No" dan langsung mengarah kepada list } \\
\text { konfirmasi pengajuan peminjaman kendaraan } \\
\text { operasional. }\end{array}$ \\
\hline C04 & $\begin{array}{l}\text { Status }=\text { Proses, Keputusan peminjaman = } \\
\text { Kendaraan Operasional, Kendaraan = B } 3022 \\
\text { KL, Supir = Select Kendaraan }\end{array}$ & $\begin{array}{l}\text { Muncul pop up mesaage dengan tulisan "Data tidak } \\
\text { dapat diproses, status supir sedang sibuk" selanjutnya } \\
\text { dapat klik "No" dan langsung mengarah kepada list } \\
\text { konfirmasi pengajuan peminjaman kendaraan } \\
\text { operasional. }\end{array}$ \\
\hline C05 & $\begin{array}{l}\text { Status }=\text { Proses, Keputusan peminjaman }= \\
\text { Kendaraan Operasional, Kendaraan = Select } \\
\text { Kendaraan, Supir = Select Kendaraan }\end{array}$ & $\begin{array}{l}\text { Muncul pop up mesaage dengan tulisan "Data tidak } \\
\text { dapat diproses, status kendaraan dan supir sedang } \\
\text { sibuk" selanjutnya dapat klik "No" dan langsung } \\
\text { mengarah kepada list konfirmasi pengajuan peminjaman } \\
\text { kendaraan operasional. }\end{array}$ \\
\hline
\end{tabular}

Sumber: Hasil Penelitian (2021)

Berdasarkan dari tabel sebelumnya dapat disimpulkan dengan diawali dengan pengisian kendaraan dan supir merupakan validasi dari tahap proses konfirmasi pengajuan peminjaman kendaraan, jika kendaraan dan atau supir tidak dapat dipilih atau tidak tersedia maka pada proses ini tidak dapat di proses dan pengajuan kembali dalam keadaan pending atau belum dapat diproses. 
Apabila semua data dapat terisi sesuai dengan test case scenario diatas, konfirmasi pengajuan peminjaman dapat diproses oleh Manager atau Admin sehingga pengajuan dapat melanjutkan ke tahap selanjutnya yaitu tahap verifikasi.

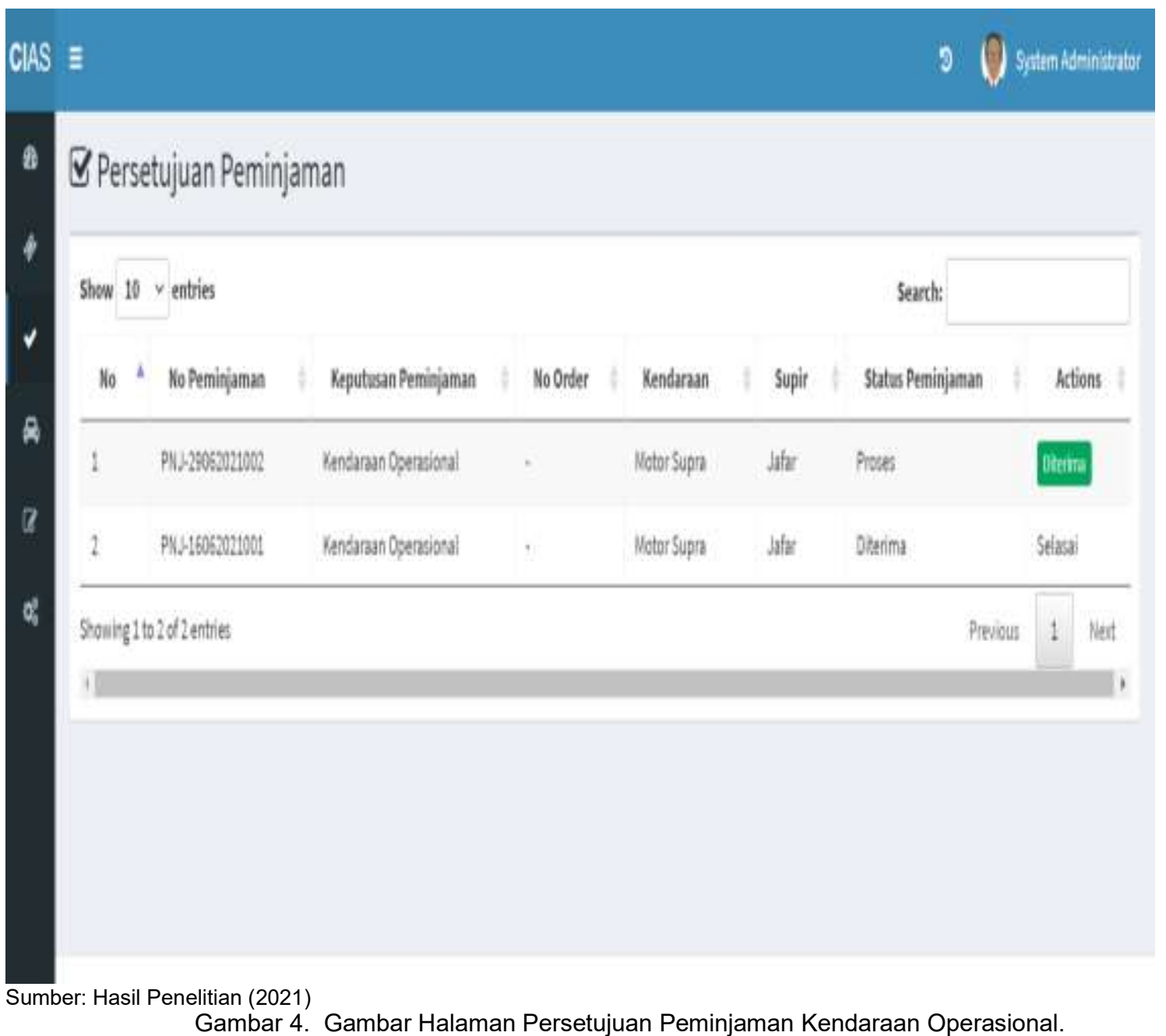

Dilihat dari gambar halaman persetujuan peminjaman kendaraan operasional. Tahap verifikasi atau persetujuan hanya dapat dilakukan oleh manager untuk memberika persetujuan setelah pengajuan telah dilakukan konfirmasi peminjaman.

Tahap ini hanya dengan klik tombol "diterima" sebagai tanda persetujuan peminjaman dengan hasil konfirmasi yang telah dilakukan oleh manager yaitu konfirmasi kendaraan dan supir. Setelah tombol "diterima" di klik maka secara otomatis sistem akan mengubah status peminjaman menjadi "diterima" dari status "proses".

Apabila status masih dalam keadaan "proses" secara otomatis konfrimasi pengajuan dari sisi kendaraan dan supir belum mendapat akses melakukan tugasnya. Berikut gambar dibawah ini pada halama persetujuan peminjaman kendaraan. Pada halaman ini dapat dibuat pengujian dengan skenario test case dalam bentuk tabel.

Tabel 4. Skenario test case Halaman Persetujuan Peminjaman Kendaraan Operasional

\begin{tabular}{lll}
\hline Kode & \multicolumn{1}{c}{ Skenario Test } & \multicolumn{1}{c}{ Hasil yang diharapkan } \\
\hline D01 & Status peminjaman = Pending & $\begin{array}{l}\text { Pada kolom "Action" akan ada tulisan "Belum diproses" } \\
\text { dan button "Diterima" tidak muncul }\end{array}$ \\
\hline D02 & Status peminjaman = Proses & $\begin{array}{l}\text { Pada kolom "Action" akan muncul button "Diterima" jika } \\
\text { di klik akan merubah status peminjaman menjadi } \\
\text { "Selesai" }\end{array}$
\end{tabular}




\begin{tabular}{ll}
\hline D03 Status peminjaman = Diterima & $\begin{array}{l}\text { Pada kolom "Action" akan ada tulisan "Selesai" dan tidak } \\
\text { dapat di klik untuk diproses kembali }\end{array}$ \\
\hline Sumber: Hasil Penelitian (2021) &
\end{tabular}

Perhatikan pada tabel skenario pengujian persetujuan peminjaman kendaraan opersional. Terdapat 3 tahap pengujian yaitu pengujian status peminjaman kendaraan operasional Pending, Proses, dan Diterima.

Apabila status peminjaman adalah Pending maka tidak dapat dilakukan proses persetujuan. Kemudian apabila status peminjaman adalah Proses maka proses persetujuan dapat dilakukan dan setelah tahap proses persetujuan telah dilakukan, status peminjaman akan berubah menjadi Diterima. Setelah itu peminjaman akan dapat dilakukan oleh peminjam.

Pada tahap ini dapat dilakukan oleh pengguna yang berada pada level Manager yang dapat mengetahui kepentingan karyawan.

Tahap selanjutnya yaitu tahap pengembalian kendaraan. Pada tahap pengembalian kendaraan dimana tahap ini dilakukan jika kendaraan sudah kembali dengan pengisian form. Data dalam list halaman pengembalian hanya muncul apabila peminjaman telah di proses persetujuan oleh manager.

Pengisian form dimulai dari dengan klik button "Proses" pada kolom Action pada halaman list pengembalian setelah itu secara otomatis akan mengarah ke halaman pengisian form pengembalian kendaraan operasional.

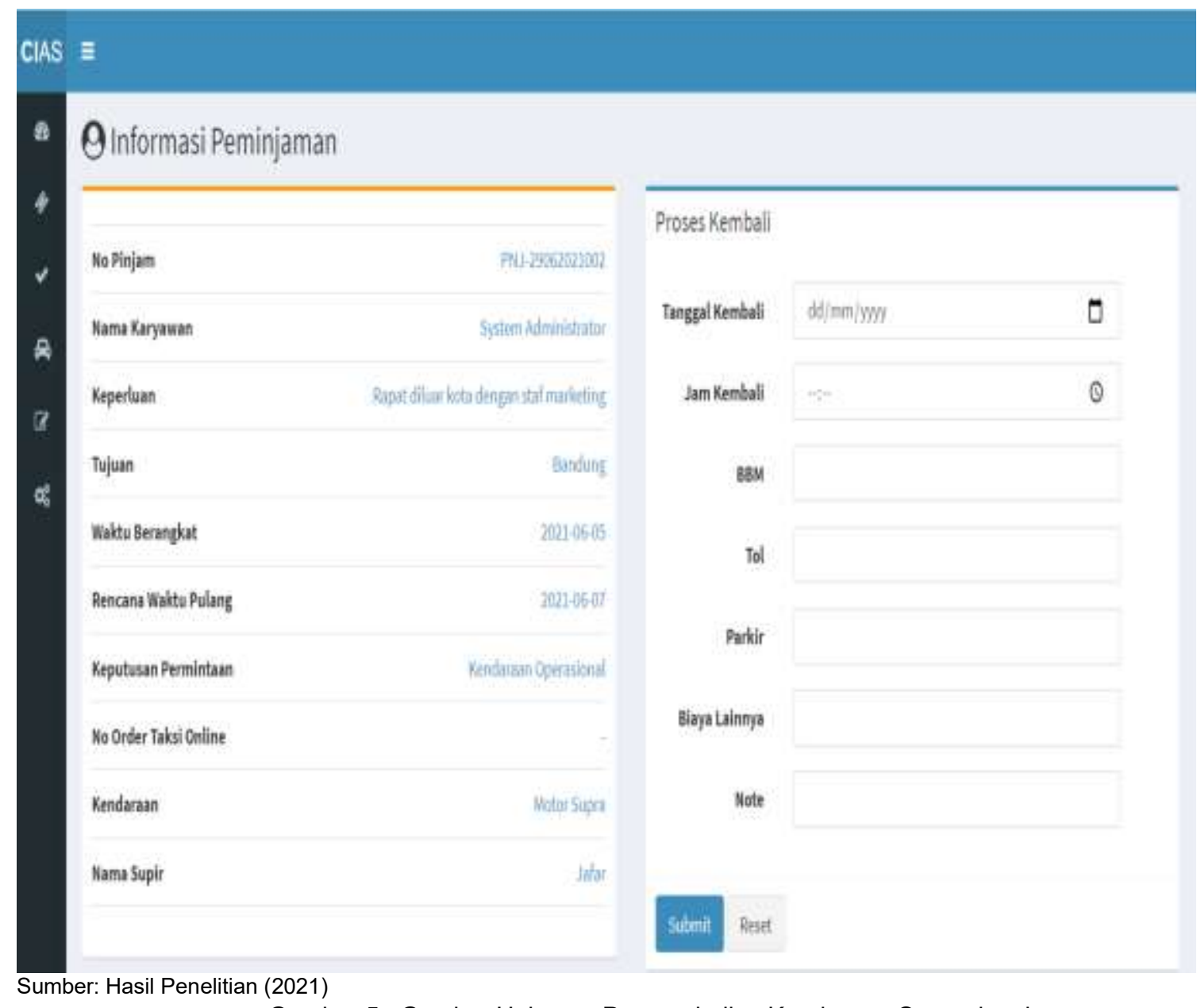

Gambar 5. Gambar Halaman Pengembalian Kendaraan Operasional.

Setelah button "Proses" di klik maka makan mengarah ke halaman form pengisian data pengembalian. Pengisian mulai dari tanggal kembali dengan isi "01/06/2021" pengambilan tanggal dapat dilakukan dengan klik icon kalender pada form tanggal dan pilih tanggal saatr kembali. 
Selanjutnya jam kembali dengan isi "20:30" atau dapat pilih jam kembali dengan klik icon jam pada form, setelah itu masukan data BBM dengan isi berupa angka dalam satuan rupiah dengan isi "200.000" setelah itu isi pada form tol berupa angka dalam satuan rupiah dengan isi "100.000" selanjutnya isi parkir berupa angka dalam satuan rupiah dengan isi "20.000" selajutnya apabila ada biaya lain-lain dapat isi "Biaya konsumsi $3 x=300.000$ " dan isi note dengan isi "Kendaraan sudah kembali".

Apabila semua sudah terisi full, dapat melakukan proses dengan klik button "Submit" setelah itu akan tampil pop up message "Data transaksi pengembalian berhasil disimpan" dan mengarah ke halaman list data pengembalian. Jika terdapat salah satu form belum terisi maka akan tampil pesan dengan tulisan "Data gagal disimpan, Data harus terisi lengkap".

Selain button "Submit" terdapat juga button "Reset" untuk mengulang kembali pengisian transaksi pengembalian jika terdapat kesalahan dalam pengisian data.

Pada halaman ini akan diperjelas dengan tabel skenario pengujian dibawah ini sehingga memudahkan dalam tahap pengujiannya.

Tabel 5. Skenario test case Halaman Pengembalian Kendaraan Operasional

\begin{tabular}{|c|c|c|}
\hline Kode & Skenario Test & Hasil yang diharapkan \\
\hline E01 & $\begin{array}{l}\text { Tanggal kembali }=01 / 06 / 2021 \text {, Jam kembali }= \\
20: 30 \text {, BBM }=200.000, \text { Tol }=100.000, \text { Parkir }= \\
20.000 \text {, Biaya Lain-lain = Biaya konsumsi } 3 x= \\
300.000, \text { Note = Kendaraan sudah kembali, klik } \\
\text { button "Submit" }\end{array}$ & $\begin{array}{l}\text { Tampil pesan "Data transaksi pengembalian berhasil } \\
\text { disimpan" dan mengarah ke halaman list pengembalian } \\
\text { dengan status kembali = "Kembali" dan Action = } \\
\text { "Selesai". Selain itu untuk kendaraan dan supir dapat } \\
\text { tampil kembali pada halaman konfirmasi kendaraan. }\end{array}$ \\
\hline E02 & $\begin{array}{l}\text { Tanggal kembali }=01 / 06 / 2021, \text { Jam kembali }= \\
20: 30 \text {, BBM }=200.000, \text { Tol }=100.000, \text { Parkir }= \\
20.000 \text {, Biaya Lain-lain = Biaya konsumsi } 3 x= \\
300.000, \text { Note = Kendaraan sudah kembali, klik } \\
\text { button "Reset" }\end{array}$ & $\begin{array}{l}\text { Tampil pesan pop up message "Yakin ingin mengulang } \\
\text { pengisian data" dan terdapat dua button yaitu "NO" dan } \\
\text { "Yes. Ketika pilih "No" maka tidak terjadi apa-apa dan } \\
\text { apabila pilih "Yes" maka data yang sudah terisi akan } \\
\text { hilang secara sistem. }\end{array}$ \\
\hline E03 & Salah satu form tidak terisi & $\begin{array}{l}\text { Tampil pesan "Data gagal disimpan, Data harus terisi } \\
\text { lengkap" dan data sudah terisi tidak hilang selanjutnya } \\
\text { transaksi dapat dilakukan kembali dengan mengisi data } \\
\text { yang kosong. }\end{array}$ \\
\hline
\end{tabular}

Sumber: Hasil Penelitian (2021)

Berdasarkan dari tabel pengujian pada halaman pengembalian kendaraan operasional terdapat tiga tahap pengujian yang dapat disimpulkan yaitu tahap pengujian pertama bahwa data yang terisi lengkap maka data akan berhasil tersimpan ke database, tahap kedua apabila klik button "Reset" dan pilih data akan hilang secara otomatis oleh sistem jika data terjadi kesalahan dan terakhir yaitu apabila pengisian data yang tidak lengkap dan melakukan penyimpan akan terdapat error dengan pesan bahwa penyimpan ke database gagal selanjutnya data dapat diisi kembali yang kurang tanpa menghilangkan data yang sudah terisi.

\section{Hasil dan Pembahasan}

Pengujian aplikasi peminjaman kendaraan operasional dapat dilakukan sebelum pengguna menggunakan aplikasi tersebut guna mengetahui dari segala kekurangan bahkan kelemahan yang terdapat pada apliikasi peminjaman kendaraan operasional.

Hasil dari pengujian dapat dijadikan sebuah kelemahan sistem apabila ditemukan sebuah kesalahan pada saat di operasikan dan kelemahan dari kesalahan sistem tersebut dapat pula dijadikan sebuah penemuan dan pengembangan sistem oleh pengguna.

Kelemahan sistem yang didapat dari hasil pengujian akan menjadi sebuah bahan perbaikan bagi pengembang sistem dan menyimpulkan bahwa sistem berhasil atau gagal.

Penyimpulan keberhasilan sistem berhasil atau tidak dapat di lakukan pembuatan tabel pengujian yang akan dilakukan dengan metode Black Box berbasis Equivalence Partitions. Berikut tabel pengujian dbawah ini.

Tabel 6. Hasil Pengujian Equivalence Partitions

\begin{tabular}{llllll}
\hline Kode & \multicolumn{1}{c}{ Skenario Test } & & Hasil yang diharapkan & Hasil pengujian & Kesimpulan \\
\hline A01 & Email & $=$ & Sistem akan membaca dan & Sistem akan membaca \\
& admin@example.com & dan & memproses kemudian sistem & dan memproses kemudian
\end{tabular}


Vol. 5, No. 2, Juni 2021, 97 - 110

\begin{tabular}{|c|c|c|c|c|}
\hline Kode & Skenario Test & Hasil yang diharapkan & Hasil pengujian & Kesimpulan \\
\hline & $\begin{array}{l}\text { password = Admin123!! } \\
\text { (untuk level admin), Email = } \\
\text { manager@gmail.com dan } \\
\text { password = Manager_321 } \\
\text { (untuk level manajer) dan } \\
\text { Email = jumari@gmail.com } \\
\text { dan password = jumari (untuk } \\
\text { level karyawan). Setelah itu } \\
\text { klik button "Sign In". }\end{array}$ & $\begin{array}{l}\text { mengarahkan } \\
\text { halaman dashboard. }\end{array}$ & $\begin{array}{lr}\text { sistem } & \text { mengarahkan } \\
\text { kepada } & \text { halaman } \\
\text { dashboard. } & \end{array}$ & \\
\hline A02 & $\begin{array}{lrr}\text { Pengisian dengan } & \text { level } \\
\text { admin sebagai satu contoh } \\
\text { yaitu } \quad \text { Email } & = \\
\text { admin@example.com } & \text { dan } \\
\text { password = Admin123! } & \end{array}$ & $\begin{array}{l}\text { Sistem akan membaca dan } \\
\text { memproses kemudian sistem } \\
\text { menampilkan pop up } \\
\text { message dengan tulisan } \\
\text { "Mohon maaf email dan } \\
\text { password salah, silahkan } \\
\text { anda periksa kembali" } \\
\text { dengan dua button yaitu } \\
\text { button "Yes" untuk } \\
\text { mengulang dan button "No" } \\
\text { untuk stop akses. }\end{array}$ & $\begin{array}{l}\text { Sistem akan membaca } \\
\text { dan memproses kemudian } \\
\text { sistem menampilkan pop } \\
\text { up message dengan } \\
\text { tulisan "Mohon maaf email } \\
\text { dan password salah, } \\
\text { silahkan anda periksa } \\
\text { kembali" dengan dua } \\
\text { button yaitu button "Yes" } \\
\text { untuk mengulang dan } \\
\text { button "No" untuk stop } \\
\text { akses. }\end{array}$ & Berhasil \\
\hline A03 & $\begin{array}{l}\text { Email dan atau password } \\
\text { kosong }\end{array}$ & $\begin{array}{l}\text { muncul pop up message } \\
\text { dengan tulisan "Email dan } \\
\text { Password tidak boleh kosong. } \\
\text { Harap diperiksa terlebih } \\
\text { dahulu". }\end{array}$ & $\begin{array}{l}\text { muncul pop up message } \\
\text { dengan tulisan "Email dan } \\
\text { Password tidak boleh } \\
\text { kosong. Harap diperiksa } \\
\text { terlebih dahulu". }\end{array}$ & Berhasil \\
\hline B01 & Form terisi semua & $\begin{array}{l}\text { Muncul pop up mesaage } \\
\text { dengan tulisan "Data berhasil } \\
\text { disimpan" dan direct ke } \\
\text { halaman list pengajuan } \\
\text { peminjaman } \\
\text { operasional. }\end{array}$ & $\begin{array}{l}\text { Muncul pop up mesaage } \\
\text { dengan tulisan "Data } \\
\text { berhasil disimpan" dan } \\
\text { direct ke halaman list } \\
\text { pengajuan peminjaman } \\
\text { kendaraan operasional. }\end{array}$ & Berhasil \\
\hline B02 & Salah satu form tidak terisi & $\begin{array}{l}\text { Muncul pop up mesaage } \\
\text { dengan tulisan "Data tidak } \\
\text { boleh kosong, silahkan cek } \\
\text { kembali" selanjutnya untuk } \\
\text { melanjutkan pengisian dapat } \\
\text { klik "Ok" dan apabila tidak } \\
\text { lanjut pengisian dapat klik } \\
\text { "No" dan langsung mengarah } \\
\text { kepada halaman list } \\
\text { pengajuan peminjaman } \\
\text { kendaraan operasional. }\end{array}$ & $\begin{array}{l}\text { Muncul pop up mesaage } \\
\text { dengan tulisan "Data tidak } \\
\text { boleh kosong, silahkan } \\
\text { cek kembali" selanjutnya } \\
\text { untuk melanjutkan } \\
\text { pengisian dapat klik "Ok" } \\
\text { dan apabila tidak lanjut } \\
\text { pengisian dapat klik "No" } \\
\text { dan langsung mengarah } \\
\text { kepada halaman list } \\
\text { pengajuan peminjaman } \\
\text { kendaraan operasional. }\end{array}$ & Berhasil \\
\hline C01 & $\begin{array}{l}\text { Status = Proses, Keputusan } \\
\text { peminjaman = Kendaraan } \\
\text { Operasional, Kendaraan = B } \\
3022 \mathrm{KL} \text {, Supir = Budi }\end{array}$ & $\begin{array}{l}\text { Muncul pop up mesaage } \\
\text { dengan tulisan "Data berhasil } \\
\text { diproses" dan mengarah ke } \\
\text { halaman list konfirmasi } \\
\text { pengajuan peminjaman } \\
\text { kendaraan operasional. }\end{array}$ & $\begin{array}{l}\text { Muncul pop up mesaage } \\
\text { dengan tulisan "Data } \\
\text { berhasil diproses" dan } \\
\text { mengarah ke halaman list } \\
\text { konfirmasi pengajuan } \\
\text { peminjaman kendaraan } \\
\text { operasional. }\end{array}$ & Berhasil \\
\hline $\mathrm{CO2}$ & $\begin{array}{l}\text { Status = Proses, Keputusan } \\
\text { peminjaman = Kendaraan } \\
\text { Operasional, Kendaraan = } \\
\text { Select Kendaraan , Supir = } \\
\text { Budi }\end{array}$ & $\begin{array}{l}\text { Muncul pop up mesaage } \\
\text { dengan tulisan "Data tidak } \\
\text { dapat diproses, status } \\
\text { kendaraan sedang sibuk" } \\
\text { selanjutnya dapat klik "No" } \\
\text { dan langsung mengarah } \\
\text { kepada list konfirmasi } \\
\text { pengajuan peminjaman } \\
\text { kendaraan operasional. }\end{array}$ & $\begin{array}{l}\text { Muncul pop up mesaage } \\
\text { dengan tulisan "Data tidak } \\
\text { dapat diproses, status } \\
\text { kendaraan sedang sibuk" } \\
\text { selanjutnya dapat klik "No" } \\
\text { dan langsung mengarah } \\
\text { kepada list konfirmasi } \\
\text { pengajuan peminjaman } \\
\text { kendaraan operasional. }\end{array}$ & Berhasil \\
\hline C03 & $\begin{array}{l}\text { Status }=\text { Proses, Keputusan } \\
\text { peminjaman }=\text { Kendaraan } \\
\text { Operasional, Kendaraan }=\mathrm{B} \\
3022 \mathrm{KL} \text {, Supir }=\text { Select } \\
\text { Kendaraan }\end{array}$ & $\begin{array}{l}\text { Muncul pop up mesaage } \\
\text { dengan tulisan "Data tidak } \\
\text { dapat diproses, status supir } \\
\text { sedang sibuk" selanjutnya } \\
\text { dapat klik "No" dan langsung } \\
\text { mengarah kepada list } \\
\text { konfirmasi } \\
\text { peminjaman pengajuan } \\
\text { operasional. }\end{array}$ & $\begin{array}{l}\text { Muncul pop up mesaage } \\
\text { dengan tulisan "Data tidak } \\
\text { dapat diproses, status } \\
\text { supir sedang sibuk" } \\
\text { selanjutnya dapat klik "No" } \\
\text { dan langsung mengarah } \\
\text { kepada list konfirmasi } \\
\text { pengajuan peminjaman } \\
\text { kendaraan operasional. }\end{array}$ & Berhasil \\
\hline C04 & $\begin{array}{l}\text { Status = Proses, Keputusan } \\
\text { peminjaman }=\text { Kendaraan }\end{array}$ & $\begin{array}{l}\text { Muncul pop up mesaage } \\
\text { dengan tulisan "Data tidak }\end{array}$ & $\begin{array}{l}\text { Muncul pop up mesaage } \\
\text { dengan tulisan "Data tidak }\end{array}$ & Berhasil \\
\hline
\end{tabular}




\begin{tabular}{|c|c|c|c|c|}
\hline Kode & Skenario Test & Hasil yang diharapkan & Hasil pengujian & Kesimpulan \\
\hline & $\begin{array}{l}\text { Operasional, Kendaraan = B } \\
3022 \mathrm{KL} \text {, Supir = Select } \\
\text { Kendaraan }\end{array}$ & $\begin{array}{lr}\text { dapat diproses, } & \text { status supir } \\
\text { sedang sibuk" selanjutnya } \\
\text { dapat klik "No" dan langsung } \\
\text { mengarah } & \text { kepada list } \\
\text { konfirmasi } & \text { pengajuan } \\
\text { peminjaman } & \text { kendaraan } \\
\text { operasional. } & \end{array}$ & $\begin{array}{l}\text { dapat diproses, status } \\
\text { supir sedang sibuk" } \\
\text { selanjutnya dapat klik "No" } \\
\text { dan langsung mengarah } \\
\text { kepada list konfirmasi } \\
\text { pengajuan peminjaman } \\
\text { kendaraan operasional. }\end{array}$ & \\
\hline C05 & $\begin{array}{l}\text { Status = Proses, Keputusan } \\
\text { peminjaman = Kendaraan } \\
\text { Operasional, Kendaraan = } \\
\text { Select Kendaraan, Supir = } \\
\text { Select Kendaraan }\end{array}$ & $\begin{array}{l}\text { Muncul pop up mesaage } \\
\text { dengan tulisan "Data tidak } \\
\text { dapat diproses, status } \\
\text { kendaraan dan supir sedang } \\
\text { sibuk" selanjutnya dapat klik } \\
\text { "No" dan langsung mengarah } \\
\text { kepada list konfirmasi } \\
\text { pengajuan peminjaman } \\
\text { kendaraan operasional. }\end{array}$ & $\begin{array}{l}\text { Muncul pop up mesaage } \\
\text { dengan tulisan "Data tidak } \\
\text { dapat diproses, status } \\
\text { kendaraan dan supir } \\
\text { sedang sibuk" selanjutnya } \\
\text { dapat klik "No" dan } \\
\text { langsung mengarah } \\
\text { kepada list konfirmasi } \\
\text { pengajuan peminjaman } \\
\text { kendaraan operasional. }\end{array}$ & Berhasil \\
\hline D01 & $\begin{array}{ll}\text { Status } & \text { peminjaman } \\
\text { Pending } & \end{array}$ & $\begin{array}{l}\text { Pada kolom "Action" akan } \\
\text { ada tulisan "Belum diproses" } \\
\text { dan button "Diterima" tidak } \\
\text { muncul }\end{array}$ & $\begin{array}{l}\text { Pada kolom "Action" akan } \\
\text { ada tulisan "Belum } \\
\text { diproses" dan button } \\
\text { "Diterima" tidak muncul }\end{array}$ & Berhasil \\
\hline D02 & Status peminjaman $=$ Proses & $\begin{array}{l}\text { Pada kolom "Action" akan } \\
\text { muncul button "Diterima" jika } \\
\text { di klik akan merubah status } \\
\text { peminjaman } \\
\text { "Selesai" }\end{array}$ & $\begin{array}{l}\text { Pada kolom "Action" akan } \\
\text { muncul button "Diterima" } \\
\text { jika di klik akan merubah } \\
\text { status peminjaman } \\
\text { menjadi "Selesai" }\end{array}$ & Berhasil \\
\hline D03 & $\begin{array}{ll}\text { Status } & \text { peminjaman } \\
\text { Diterima } & \end{array}$ & $\begin{array}{l}\text { Pada kolom "Action" akan } \\
\text { ada tulisan "Selesai" dan } \\
\text { tidak dapat di klik untuk } \\
\text { diproses kembali }\end{array}$ & $\begin{array}{l}\text { Pada kolom "Action" akan } \\
\text { ada tulisan "Selesai" dan } \\
\text { tidak dapat di klik untuk } \\
\text { diproses kembali }\end{array}$ & Berhasil \\
\hline E01 & $\begin{array}{l}\text { Tanggal kembali }= \\
01 / 06 / 2021, \text { Jam kembali }= \\
20: 30, \text { BBM }=200.000, \text { Tol }= \\
100.000, \text { Parkir }=20.000, \\
\text { Biaya Lain-lain }=\quad \text { Biaya } \\
\text { konsumsi } 3 x=300.000, \text { Note } \\
=\text { Kendaraan sudah kembali, } \\
\text { klik button "Submit" }\end{array}$ & $\begin{array}{l}\text { Tampil pesan "Data transaksi } \\
\text { pengembalian berhasil } \\
\text { disimpan" dan mengarah ke } \\
\text { halaman list pengembalian } \\
\text { dengan status kembali = } \\
\text { "Kembali" dan Action = } \\
\text { "Selesai". Selain itu untuk } \\
\text { kendaraan dan supir dapat } \\
\text { tampil kembali pada halaman } \\
\text { konfirmasi kendaraan. }\end{array}$ & $\begin{array}{l}\text { Tampil pesan "Data } \\
\text { transaksi pengembalian } \\
\text { berhasil disimpan" dan } \\
\text { mengarah ke halaman list } \\
\text { pengembalian dengan } \\
\text { status kembali = "Kembali" } \\
\text { dan Action = "Selesai". } \\
\text { Selain itu untuk kendaraan } \\
\text { dan supir dapat tampil } \\
\text { kembali pada halaman } \\
\text { konfirmasi kendaraan. }\end{array}$ & Berhasil \\
\hline E02 & $\begin{array}{l}\text { Tanggal kembali }= \\
01 / 06 / 2021, \text { Jam kembali }= \\
20: 30, \text { BBM }=200.000, \text { Tol }= \\
100.000, \text { Parkir }=20.000, \\
\text { Biaya Lain-lain }=\quad \text { Biaya } \\
\text { konsumsi } 3 x=300.000, \text { Note } \\
=\text { Kendaraan sudah kembali, } \\
\text { klik button "Reset" }\end{array}$ & $\begin{array}{l}\text { Tampil pesan pop up } \\
\text { message "Yakin ingin } \\
\text { mengulang pengisian data" } \\
\text { dan terdapat dua button yaitu } \\
\text { "NO" dan "Yes. Ketika pilih } \\
\text { "No" maka tidak terjadi apa- } \\
\text { apa dan apabila pilih "Yes" } \\
\text { maka data yang sudah terisi } \\
\text { akan hilang secara sistem. }\end{array}$ & $\begin{array}{l}\text { Tampil pesan pop up } \\
\text { message "Yakin ingin } \\
\text { mengulang pengisian } \\
\text { data" dan terdapat dua } \\
\text { button yaitu "NO" dan } \\
\text { "Yes. Ketika pilih "No" } \\
\text { maka tidak terjadi apa-apa } \\
\text { dan apabila pilih "Yes" } \\
\text { maka data yang sudah } \\
\text { terisi akan hilang secara } \\
\text { sistem. }\end{array}$ & Berhasil \\
\hline E03 & Salah satu form tidak terisi & $\begin{array}{l}\text { Tampil pesan "Data gagal } \\
\text { disimpan, Data harus terisi } \\
\text { lengkap" dan data sudah } \\
\text { terisi tidak hilang selanjutnya } \\
\text { transaksi dapat dilakukan } \\
\text { kembali dengan mengisi data } \\
\text { yang kosong. }\end{array}$ & $\begin{array}{l}\text { Tampil pesan "Data gagal } \\
\text { disimpan, Data harus terisi } \\
\text { lengkap" dan data sudah } \\
\text { terisi tidak hilang } \\
\text { selanjutnya transaksi } \\
\text { dapat dilakukan kembali } \\
\text { dengan mengisi data yang } \\
\text { kosong. }\end{array}$ & Berhasil \\
\hline
\end{tabular}

Sumber: Hasil Penelitian (2021)

Berdasarkan dari tabel hasil pengujian dengan Equivalence Partitions dapat disimpulkan bahwa tingkat keberhasilan oleh sistem yang dikembangkan dalam menangani dan mengolah data kendaraan operasional perusahaan dinyatakan berhasil. Tingkat keberhasilan aplikasi ini dengan tidak ditemukan kesalahan. 
Vol. 5, No. 2, Juni 2021, 97 - 110

\section{Kesimpulan}

Proses dan hasil pengujian Black Box dengan metode Equivalence Partioning yang dilakukan pada aplikasi peminjaman kendaraan operasional perusahaan dapat dinyatakan bahwa aplikasi ini tidak terdapat kelemahan bahkan kekurangan dari segi fungsionalitas sistem berjalan sesuai dengan hasil yang inginkan oleh perusahaan. Saran adalah pegujian tidak hanya sampai disini, perlu adanya pengujian=pengujian fase berikutnya apabila terjadi kesalahan akibat termakan waktu.

\section{Referensi}

[1] N. Botutihe, "Analisis Mekanisme Penggunaan Kendaraan Operasional Pada Kantor Sekretariat Daerah Kota Gorontalo," Publik (Jurnal IImu Adm., vol. 6, no. 2, p. 79, 2018, doi: 10.31314/pjia.6.2.79-86.2017.

[2] D. Yusuf and D. B. Srisulistiowati, "Sistem Pendukung Keputusan Pembelian Kendaraan Operasional Menggunakan Metode Ahp," JSI (Jurnal ..., 2021, [Online]. Available: https://journal.universitassuryadarma.ac.id/index.php/jsi/article/view/614.

[3] A. Kuswoyo, K. Akuntansi, K. Akuntansi, C. Diagram, A. Collections, and B. Lampung, "PENGEMBANGAN APLIKASI PENJUALAN BARANG PADA BUTIK AGRIS," vol. 21, no. 1, pp. 530-536, 2021.

[4] D. Sulias and M. Ardhiansyah, "Aplikasi E-Commerce Berbasis Web Dengan Menggunakan Model Extreme Programming ( Xp )," pp. 190-199, 2020.

[5] M. S. Mustaqbal, R. F. Firdaus, and H. Rahmadi, "PENGUJIAN APLIKASI MENGGUNAKAN BLACK BOX TESTING BOUNDARY VALUE ANALYSIS (Studi Kasus : Aplikasi Prediksi Kelulusan SNMPTN)," vol. I, no. 3, pp. 31-36, 2015.

[6] B. A. Priyaungga, D. B. Aji, M. Syahroni, N. T. S. Aji, and A. Saifudin, "Pengujian Black Box pada Aplikasi Perpustakaan Menggunakan Teknik Equivalence Partitions," J. Teknol. Sist. Inf. dan Apl., vol. 3, no. 3, p. 150, 2020, doi: 10.32493/jtsi.v3i3.5343.

[7] A. Rouf, "Pengujian perangkat lunak dengan menggunakan metode white box dan black box," pp. 1-7.

[8] I. D. L. - AMIK BSI Purwokerto and F. R. - AMIK BSI Purwokerto, "Sistem Informasi Penjualan Merchandise Berbasis Web Pada PT Come Indonusa Dengan Metode Waterfall," Evolusi J. Sains dan Manaj., vol. 6, no. 2, pp. 91-97, 2018, doi: 10.31294/evolusi.v6i2.4469.

[9] T. Hidayat and M. Muttaqin, "Pengujian Sistem Informasi Pendaftaran dan Pembayaran Wisuda Online menggunakan Black Box Testing dengan Metode Equivalence Partitioning dan Boundary Value Analysis," J. Tek. Inform. UNIS JUTIS, vol. 6, no. 1, pp. 2252-5351, 2018, [Online]. Available: www.ccssenet.org/cis.

[10] H. Hendri, J. W. Hasiholan Manurung, R. A. Ferian, W. F. Hanaatmoko, and Y. Yulianti, "Pengujian Black Box pada Aplikasi Sistem Informasi Pengelolaan Masjid Menggunakan Teknik Equivalence Partitions," J. Teknol. Sist. Inf. dan Apl., vol. 3, no. 2, p. 107, 2020, doi: $10.32493 / j$ tsi.v3i2.4694. 
[11] T. Hidayat and H. D. Putri, "Testing Student Portal on Academic Information Systems (SINA) using Black Box Testing with Equivalence Partitioning Methods and Boundary Value Analysis (in Bahasa: Pengujian Portal Mahasiswa pada Sistem Informasi Akademik ( SINA ) menggunakan Black Box T," J. Inform. Pengemb. IT, vol. 7, no. 1, pp. 83-92, 2019.

[12] J. Susanto, M. M. Junaidi, Y. Sudrajat, and T. Desyani, "Pengujian Black Box pada Aplikasi Desktop Penjualan Elektronik Menggunakan Metode Equivalence Partitioning," vol. 4, no. 1, pp. 52-57, 2021, doi: 10.32493/jtsi.v4i1.8519. 